\title{
Influence of Rice Husk Ash on Sub-Grade Bearing Strength in Stabilization of Expansive Soils for Low Volume Roads in Kenya
}

\author{
Catherine Mugai $^{1 *} \quad$ Dr. Eng. Benedette Sabuni ${ }^{2} \quad$ Dr. Edward Neyole ${ }^{3} \quad$ Dr Faith Mugai ${ }^{4}$ \\ 1.Postgraduate Student. P.O. Box 56447 - 00200, Nairobi, Kenya \\ 2.School of Engineering and Built Environment, Masinde Muliro University of Science \& Technology \\ 3.Department of Disaster Preparedness \& Sustainable Development, Masinde Muliro University of Science \& \\ Technology \\ 4.School of Public Health, Mount Kenya University
}

\begin{abstract}
The cost of cement and lime used in stabilizing soils can be reduced by using locally available rice husk ash which is known to contain pozzolanic properties. This paper studies the variations in sub-grade bearing strength of clay when rice husk ash (RHA), lime and cement are added in varying proportions. Chemical analysis was first carried out to establish the silica content in the RHA. CBR test was conducted to establish the strength properties of the various soil mixes. RHA was used as the main stabilizing agent added at varying proportions of $0 \%, 5 \%, 10 \%$, $15 \%$ and $20 \%$. Lime and cement proportions were constant in each batch but varied across the six batches as $0 \%$, $2 \%$ lime, $4 \%$ lime, $6 \%$ lime, $1.5 \%$ cement and $2 \%$ cement. The test results show that RHA in combination with lime can be used as an economic and eco friendly stabilizing agent giving a significant improvement in the subgrade bearing strength of cotton soil.
\end{abstract}

Keywords: key words, Rice Husk Ash (RHA), California Bearing Ratio (CBR), Sub-grade, Lime, Cement

DOI: $10.7176 / \mathrm{CER} / 12-11-04$

Publication date: November $30^{\text {th }} 2020$

\section{Introduction}

The cost of cement and lime used in stabilizing soils in Kenya can be reduced by using locally available rice husk ash which is known to contain pozzolanic properties. Rice husks are considered to have negative environmental impact because they decompose slowly and cannot be used as manure. Many studies have been done on the use of rice husk ash in stabilizing soil however there are no studies specific to low volume road construction. One of the strategies being pursued under the Vision 2030 plan on improvement of infrastructure entails enhancing local content on identified infrastructure projects to minimize import content. Samples of rice husks were collected from Kirinyaga County because of rice production and availability of rice husks in the area. 100kg of black cotton soil was also collected from the field and delivered to the Government's material testing laboratory. Chemical analysis done on the RHA established that it contains $96.35 \%$ silica making it a good pozzolanic material. Six batches were prepared; each batch had RHA added at uniform increment of $0 \%, 5 \%, 10 \%, 15 \%$ and $20 \%$ in all the batches. Constant percentages of lime and cement were added in each batch. The sub-grade bearing strength class of cotton soil increased from soil class S1 (2-5\% CBR) to S3 (7-13\% CBR) using two combinations with the least additives; $2 \%$ lime mixed with $5 \%$ RHA and $4 \%$ lime alone. The results obtained from this study can be used as a guideline in stabilizing materials for the sub-grade layers on low volume roads in Kenya. In addition, the findings of this research can form a basis for further research on other applications of rice husk ash in the construction industry in Kenya with the aim of finding economical solutions and preservation of non-renewable resources such as soils and rocks.

\section{Materials Used}

Rice Husks Ash was sourced from Mwea, Kirinyaga County in Kenya. 2 sacks of 50Kg size were filled with properly burned rice husk from Mwea Rice mill fields. The ash was collected by scooping using a spade and filling into sacks. $5 \mathrm{Kg}$ of rice husks were also collected to be burned in a furnace for chemical analysis. The samples were then delivered to the laboratory.

Black cotton soil samples were collected from Marura and Kangai wards in Kirinyaga County. 4 No. holes, 2 from each ward were dug. The holes were $1 \mathrm{~m}$ wide by $1 \mathrm{~m}$ long to allow sufficient working space. The upper $300 \mathrm{~mm}$ layer containing organic matter was discarded. One hole was excavated to the bottom of the clay soil layer and it was established to be up to $2 \mathrm{~m}$ depth. Soil was then collected from the other three holes up to a depth not exceeding $1 \mathrm{~m}$ as the quantities were sufficient. The soil was then packed in sacks and loaded onto a pickup then delivered to the laboratories. The holes were then filled up with nearby surrounding materials. Lime and cement were bought from a local hardware. 


\section{Methodology}

\subsection{Sample Preparation}

The soil sample was sufficiently dried to laboratory moisture conditions then sieved using a $5 \mathrm{~mm}$ sieve. To obtain a sample for sieve analysis, a riffle box was used where quartering of the sample was done.

\subsection{Chemical analysis}

A sample of rice husks was burnt at $550^{\circ} \mathrm{C}$. The ash content was determined by measuring the weight of the sample before burning and after burning. Chemical analysis was carried out to determine chemical composition of the ash. $\mathrm{PH}$ value of RHA was determined in accordance with BS 1377:1775

\subsection{California Bearing Ratio (CBR)}

i. The mass of soil to be used in the CBR test was first determined using proctor compaction test. This was done by considering the maximum dry density and optimum moisture content as determined from the Proctor test.

ii. $\quad$ From the mass obtained in (i) the wet mass to use for 3 layers was determined

iii. The actual mass of wet material per mould with an addition of $500 \mathrm{~g}$ was determined

iv. The dry mass per mould which considered the total wet mass and the present moisture content was determined

v. The water to be added when mixing was then determined which is the product of the total dry mass and difference of optimum moisture content (OMC) and present moisture content (PMC)

vi. The measured out sample was mixed with water determined in (v)

vii. The soil was placed in the mould in three layers. A filter paper was placed at the bottom of the mould and top of the sample

viii. $\quad$ The mould with the compacted soil was then placed in a soaking tank for 4 days

ix. On the 4th day, the sample was removed and allowed to drain water for about 15 minutes.

x. For stabilized soils, the compacted soil was covered using wax and left to cure for 7 days in air and then the samples were soaked for 7 days before testing.

xi. The sample in the mould was then assembled in the loading machine and penetration carried out on both sides of the mould

\section{Results and Discussion}

\subsection{Chemical Analysis}

The study sought to first find out the chemical properties of rice husk ash in order to establish if it is a pozzolanic material. Pozzolanas are siliceous and/or aluminous materials, which in themselves possess little or no cementing properties, but chemically react with calcium hydroxide, such as lime, to form compounds possessing cementitious properties (Behak, 2017). The oxide composition of RHA is shown in Table 4-1 below. The composition of silica, $\mathrm{SiO}_{2}$, is $96.35 \%$ which is the highest concentration of plant residue. This shows that it is a good pozzolana that could help mobilize the $\mathrm{CaOH}$ in the soil for the formation of cementitious compounds.

PH of RHA was found to be 8.731 which, according to BS1924, is below the required 12 ph value hence there would be no influence of RHA on the PH of soil. Influence of RHA in stabilization will therefore address other parameters.

\subsection{Strength (CBR)}

California bearing ratio for black cotton soil was recorded for neat soil after 4 days soaking without cure. The CBR was also obtained for the treated soil which was first cured for 7 days and soaked for 7 days. The results are as indicated in table 4.2 . 
Table 4.2: CBR of black cotton soil after 7 days curing and 7 days soak

\begin{tabular}{|c|c|c|c|c|c|c|}
\hline Batch & Mix Proportions & $\begin{array}{l}\text { CBR (\%) Value } \\
\text { after } 7 \text { Days } \\
\text { Curing \& } 7 \text { Days } \\
\text { Soak }\end{array}$ & $\begin{array}{l}\text { Sub-grade } \\
\text { Bearing } \\
\text { Strength } \\
\text { Class }\end{array}$ & $\begin{array}{l}\text { Pearson's } \\
\text { correlation } \\
\text { coefficient }\end{array}$ & $\begin{array}{c}\text { Statistical } \\
\text { Significance } \\
\text { of the test } \\
(P-\text { Value })\end{array}$ & Remark/Interpretation \\
\hline \multirow{5}{*}{1} & $S B$ & $\begin{array}{c}\text { (no cure, } 4 \\
\text { days soak) }\end{array}$ & $S 1$ & \multirow{5}{*}{0.64} & \multirow{5}{*}{0.2452} & \multirow{5}{*}{$\begin{array}{l}\text { No statistically significant } \\
\text { correlation between \% increase in } \\
\text { Rice Husk Concentration and CBR } \\
\text { for this mixture } \\
(P \text {-value }>0.05\end{array}$} \\
\hline & $S B+5 \% R$ & 1 & $S 1$ & & & \\
\hline & $S B+10 \% R$ & 2 & $S 1$ & & & \\
\hline & $S B+15 \% R$ & 3 & $S 1$ & & & \\
\hline & $S B+20 \% R$ & 5 & $S 2$ & & & \\
\hline \multirow{5}{*}{2} & $S B+2 \% L$ & 7 & $S 2$ & \multirow{5}{*}{0.99} & \multirow{5}{*}{0.0019} & \multirow{5}{*}{$\begin{array}{l}\text { Statistically significant correlation } \\
\text { between \% increase in Rice Husk } \\
\text { Concentration and CBR for this } \\
\text { mixture } \\
(\text { P-value }<0.05 \text { ) } \\
\text { [positive correlation] }\end{array}$} \\
\hline & $S B+5 \% R+2 \% L$ & 9 & $S 3$ & & & \\
\hline & $S B+10 \% R+2 \% L$ & 10 & $S 3$ & & & \\
\hline & $S B+15 \% R+2 \% L$ & 11 & S3 & & & \\
\hline & $S B+20 \% R+2 \% L$ & 12 & $S 3$ & & & \\
\hline \multirow{5}{*}{3} & $S B+4 \% L$ & 11 & $S 3$ & \multirow{5}{*}{0.94} & \multirow{5}{*}{0.0162} & \multirow{5}{*}{$\begin{array}{l}\text { Statistically significant correlation } \\
\text { between \% increase in Rice Husk } \\
\text { Concentration and CBR for this } \\
\text { mixture } \\
(\text { P-value }<0.05) \\
\text { [positive correlation] }\end{array}$} \\
\hline & $S B+5 \% R+4 \% L$ & 12 & $S 3$ & & & \\
\hline & $S B+10 \% R+4 \% L$ & 13 & $S 3$ & & & \\
\hline & $S B+15 \% R+4 \% L$ & 18 & $S 5$ & & & \\
\hline & $S B+20 \% R+4 \% L$ & 23 & $S 5$ & & & \\
\hline \multirow{5}{*}{4} & $S B+6 \% L$ & 17 & $S 5$ & \multirow{5}{*}{-0.97} & \multirow{5}{*}{0.0060} & \multirow{5}{*}{$\begin{array}{l}\text { Statistically significant correlation } \\
\text { between \% increase in Rice Husk } \\
\text { Concentration and CBR for this } \\
\text { mixture } \\
(\text { P-value }<0.05) \\
\text { [negative correlation] }\end{array}$} \\
\hline & $S B+5 \% R+6 \% L$ & 17 & $S 5$ & & & \\
\hline & $S B+10 \% R+6 \% L$ & 15 & $S 4$ & & & \\
\hline & $S B+15 \% R+6 \% L$ & 13 & $S 4$ & & & \\
\hline & $S B+20 \% R+6 \% L$ & 12 & $S 4$ & & & \\
\hline \multirow{5}{*}{5} & $S B+1.5 \% C$ & 20 & $S 5$ & \multirow{5}{*}{0.98} & \multirow{5}{*}{0.0024} & \multirow{5}{*}{$\begin{array}{l}\text { Statistically significant correlation } \\
\text { between \% increase in Rice Husk } \\
\text { Concentration and CBR for this } \\
\text { mixture } \\
(\text { P-value }<0.05 \text { ) } \\
\text { Ipositive correlation }\end{array}$} \\
\hline & $S B+5 \% R+1.5 \% C$ & 22 & S5 & & & \\
\hline & $S B+10 \% R+1.5 \% C$ & 24 & S5 & & & \\
\hline & $S B+15 \% R+1.5 \% C$ & 29 & $S 5$ & & & \\
\hline & $S B+20 \% R+1.5 \% C$ & 32 & S6 & & & \\
\hline \multirow{5}{*}{6} & $S B+2 \% C$ & 21 & $S 5$ & \multirow{5}{*}{1.00} & \multirow{5}{*}{0.0003} & \multirow{5}{*}{$\begin{array}{l}\text { Statistically significant correlation } \\
\text { between \% increase in Rice Husk } \\
\text { Concentration and CBT for this } \\
\text { mixture } \\
(\text { P-value }<0.05) \\
\text { [positive correlation }\end{array}$} \\
\hline & $S B+5 \% R+2 \% C$ & 24 & $S 5$ & & & \\
\hline & $S B+10 \% R+2 \% C$ & 28 & $S 5$ & & & \\
\hline & $S B+15 \% R+2 \% C$ & 31 & $S 6$ & & & \\
\hline & $S B+20 \% R+2 \% C$ & 36 & S6 & & & \\
\hline
\end{tabular}

From table 4.2, the CBR of black cotton soil improved from sub-grade class S1 to S3 with batch 2 and batch 3 mixes, the minimum ratio of additives being;

a. $2 \%$ lime and 5\% RHA added to black cotton soil

b. $4 \%$ lime added to black cotton soil

Pavement Design Guidelines for Low Volume Roads in Kenya stipulates a minimum of S2 soils for subgrade therefore for design purposes, S3 soils can be considered. Batches 4, 5 and 6 produced sub-grade classes S4, S5 and S6 which are uneconomical for low volume roads. From the table, cement treated soil had higher CBR values than lime treated soils. There was statistically significant correlation between percentage increase in RHA and CBR values for all the batches except the first batch.

The increase in CBR due to addition of RHA may be attributed to the gradual formation of cementatious compounds between the RHA and $\mathrm{CaOH}$ naturally present in the soil (Alhassan-2008). The results are consistent with observations made by (Yadu, L.,Tripathi, R. K. \& Singh, 2011) where they found the CBR of neat soil increased with addition of Rice husk ash.

Lime improves the strength of clay by three mechanisms: hydration, flocculation, and cementation. The first and second mechanisms occur almost immediately upon introducing the lime, while the third is a prolonged effect (Patel \& Patel, 2012).

Ampera \& Aydogmust (2005) treated Chemnitz clayey soil [according to Association of State Highway and Transportation Officials (AASHTO)] using lime $(2,4$, and 6\%) and cement $(3,6$, and 9\%). They conducted compaction and strength tests on treated and untreated specimens. They concluded that the strength of cementtreated soil was generally greater than the strength of lime treated soil.

\section{Conclusion}

From the results obtained, two combinations of minimum materials improved the sub-grade bearing strength class of black cotton soil from $\mathrm{S} 1$ to class $\mathrm{S} 3$;
a. Addition of $2 \%$ lime and $5 \%$ RHA.
b. With addition of $4 \%$ lime. 
According to the RDM Part III chapter 6 (1987), There is no allowance for laying a pavement on soils with CBR values that are below 2. The use of S1 soils (CBR 2-5) as direct support for pavements should be avoided as much as possible. Such soils should be replaced or covered with improved sub-grade. The study found that stabilizing expansive sub-grade soil using 2\% lime and 5\% RHA can make it suitable for direct support of a pavement or make it suitable for improving with a capping layer of thickness and quality specified in the pavement design guidelines.

\section{References}

Adhikary, S., \& Jana, K. (2016). Potentials of Rice-Husk Ash As a Soil Stabilizer. International Journal of Latest Research in Engineering and Technology, 2(2), 40-48.

Alhassan, M. (2008). POTENTIALS OF RICE HUSK ASH FOR SOIL STABILIZING. 11(4), 246-250. Retrieved from https://mospace.umsystem.edu/xmlui/bitstream/handle/10355/49217/Divyateja_SarapuRHA.pdf? sequence $=1 \&$ is Allowed $=\mathrm{y}$

Chief Engineer R. (1987). ROAD DESIGN MANUAL PART III.

Chief Engineer M. (2017). Pavement Design Guidelines For Low Volume Sealed Roads (PDG1).

Choobbasti, A. J., Ghodrat, H., Vahdatirad, M. J., Firouzian, S., Barari, A., Torabi, M., \& Bagherian, A. (2010). Influence of using rice husk ash in soil stabilization method with lime. Frontiers of Earth Science in China, 4(4), 471-480. https://doi.org/10.1007/s11707-010-0138-x

Kirinyaga County Plan. (2017). Republic of Kenya Kirinyaga County First County Integrated ( Draft).

Ministry of Roads and Public Works, N. (1986). Standard Specification for State Road and Bridge Construction. Nairobi: Ministry of Roads and Public Works.

Patel, M. A., \& Patel, H. S. (2012). A Review on Effects ffects of Stabilizing Agents for Stabilization tabilization of Weak Soil. 2(6), 1-7.

Yadu, L.,Tripathi, R. K. \& Singh, D. (2011). Comparison of fly ash and rice husk ash htabilized black cotton soil. International Journal of Earth Sciences and Engineering, 4(6), 42-45. 